Rupantaran : A Multidisciplinary Journal

Vol. III : 119-130, March, 2020

ISSN : 2091-0061

Research Management Cell (RMC)

Dhankuta Multiple Campus, Dhankuta

Tribhuvan University, Nepal

\title{
'दलबहादुर' खण्डकाव्यमा अलङ्कारविधान
}

\author{
कृष्णगोविन्द अधिकारी ${ }^{9}$ \\ इमेल : krishnagovinda56@gmail.com
}

\section{सार}

'दलबहादुर' खण्डकाव्यका खण्डकाव्यकार कृष्णप्रसाद वस्ती हुन् । उनको 'दलबहादुर' खण्डकाव्य र सो काव्यमा विधान गरिएका प्रमुख अलड्कारहरूलाई चिनाउने उद्देश्यका साथ तयार पारिएको प्रस्तुत लेखको शीर्षक 'वस्ती गुरुको 'दलबहादुर' खण्डकाव्यमा अलड़कारविधान हो'। वस्ती गुरुको जीवनी व्यक्तित्व, कृतित्व तथा पूर्वीय समालोचना पद्धतिको एक प्रमुख सम्प्रदाय अलड्कारवाद अनुरूप 'दलबहादुर' खण्डकाव्यमा के कस्ता अलड्कारहरूको विधान गरिएको छ। त्यसका लागि अध्ययन गरिएका सामग्रीहरूमा उनकै स्मृतिमा प्रकाशित स्मृतिग्रन्थ र त्यही ग्रन्थमा समेटिएको 'दलबहादुर' खण्डकाव्य र त्यसको पृष्ठभूमि, लेखहरू, समालोचनात्मक पुस्तक, शब्दकोशादि प्रमुख हुन् । यस लेखमा खण्डकाव्यकारको सड्क्षिप्त जीवनी, कृतिको विवरण, 'दलबहादुर' खण्डकाव्यको कथावस्तु, वशेषता र अलड्कारको परिचय सहित यस काव्यमा विधान गरिएका 99 ओटा अलड़कारको सलक्षण विश्लेषणत्मक अध्ययन गरिएको छ । यस अध्ययनवाट पूर्वीय काव्यशास्त्र अन्तर्गतको अलड़कार सिद्धान्तको प्रयोगात्मक पक्षलाई नेपाली भाषामा कविता रचना गर्ने कविहरूले कसरी त्यसको विधान गदर्दरहेछन् भन्ने अध्ययन गर्न खोजिएको छ। यसरी हेर्दा कविहरूले अलङ्कार प्रस्तुतिकै लागि कविताकाव्यको रचना गर्दा रहेछन् कि कविताकाव्य रचना गर्दे जाँदा अलड्कारको आयोजना स्वतःस्फूर्त रूपमा हुँदै जाँदोरहेछ, भन्ने कुरा हेरिएको छ। यसरी हेर्दा कवि वस्ती आलड्कार प्रस्तुतिका लागि कविता लेख्ने कवि होइन रहेछन् । बरु उनले कविताकाव्य रचना गर्देजाँदा अलड्कारहरूको विधान स्वतः हुँदै जाँदो रहेछ भन्ने कुरा देखिएको छ।

मुख्य शब्दावली : शब्दालड्कार, अर्थालड्कार, लक्षण, विधान

\section{परिचय}

नेपाली कविताकाव्यको क्षेत्रमा आफ्नो छुट्टै परिचय स्थापित गर्न सफल कवि कृष्णप्रसाद वस्तीको जन्म वि.सं. १९६६ साल असार १६ गते धनकुटाको फलाँटेमा र मृत्यु २०७१ साल श्रावण ३१ गते विश्रान्ति मन्दिर, धनकुटामा नै भएको हो। हालको नेपालको डोटी जिल्लामा पर्ने वस्ता भन्ने ठाउँबाट उनका पुर्खा नन्दराम फलाँटेमा आई फलाँटको जड्गल फाँडेर बसोबास गरेका हुदाँ ठाउँको नाम नै फलाँटे रहन गएछ भने वस्ताबाट आई बसाबास गरेका हुँदा उनीहरूलाई वस्ती भानिएको रहेछ। कालान्तरमा यो नै उनीहको थर कायम हुनपुगेको देखियो। कृष्णप्रसाद पिता डिल्लीराम र माता पवित्रादेवी (भट्टराई) वस्तीका गर्भबाट जन्मिएका जेठा सन्तान हुन् । उनको न्वारनको नाम 'खे' अक्षरबाट उठेको भएपनि उनकी हजुरआमा गौरादेवी (घिमिरे) वस्तीले उनलाई कृष्णप्रसाद भनी बोलाउने गरेकाले भविष्यमा उनको नाम नै कृष्णप्रसाद वस्ती रहन पुग्यो। उनको पालन पोषण र शिक्षादीक्षामा उनकी हजुरआमा (आमै) को ठूलो योगदान रहेको देखिन्छ, (स्मृतिग्रन्थ : ९६४)।

9. लेखक त्रि.वि. धनकुटा बहुमुखी क्याम्पस, धनकुटामा नेपाली विषयको उपप्राध्यापक पदमा कार्यरत हुनुहुन्छ। 
फलाँटेकै खोलाखर्कको साँखेडाँडामा कार्कीहरूद्वारा सन्चालित हिउँदे पाठशालाका शिक्षक भएका आफ्नै पिताबाट नै अक्षरारम्भ र प्रारम्भिक शिक्षा प्राप्तगरेका कृष्णप्रसादले रामायण, चण्डी पढ्नसक्ने भएपछि, धनकुटाकै ताड्खुवाको ढुड्गेमा फुपूका घरमा बसेर त्यहीं दाजु काशीनाथ कट्टेलले खोलेको हिउँदे पाठशालामा पढी रुद्री समेत पढ़्नसक्ने भएछन् (स्मृतिग्रन्थ : ९९९)। पछि, २००२ सालमा आमाले दिएको रु.१०। खर्च बोकेर गाउँकै चन्द्रबहादुर कार्कीसँग वनारस पुगेका वस्तीले त्यहाँको युगलकिशोर पाठशालाबाट प्रथमासम्मको अध्ययन गरे । त्यसपछि, काशीकै मारवाडी संस्कृत विद्यालयबाट २००९ सालमा मध्ययमा र राजकीय संस्कृत महाविद्यालयबाट शास्त्री एवम् वाराणसेय संस्कृत विश्वविद्यालयबाट २०१४ सालमा साहित्य विषयमा आचार्य तहसम्मको औपचारिक शिक्षा हाँसिल गरे। त्यस्तै उनले त्रि.वि. बाट संस्कृत भाषा विषयमा एम.ए.गर्दा सर्वोत्कृष्ट नतिजा ल्याउन सफल भई २०२६ सालको महेन्द्र विद्याभूषण पदक समेत प्राप्तगरे। अध्ययनमा लगनशील वस्तीले सेवानिवृत्त भएपशचात् पनि औपचारिक अध्ययन गरी ने.सं.वि.बाट २०४६ सालमा पुराणेतिहास विषयमा प्रथम श्रेणीमा आचार्य तह उत्तीर्ण गरे ।

कष्णप्रसादले वनारसमा अध्ययन गर्दाकै समय (२००६ देखि २०१५ सम्म) देखि नै फलाँटेकै अमर मिडिल स्कुल हुँदै अध्यापन गर्न सुरु गरेका थिए। पछि, धनकुटा, सुनसरी, भापाका विभिन्न ठाउँ हुँदै २०१७ सालदेखि विराटनगरको आदर्श विद्यालयमा स्थायी शिक्षक भई शिक्षण गरिरहेका थिए। त्यही समयमा २०२३ सालदेखि धनकुटा बहुमुखी क्याम्पस (तत्कालीन डिग्री कलेज) मा प्राध्यापन गर्नका लागि उनलाई बोलाइयो । उनले धनकुटामा आई प्राध्यापन गर्दे गर्दा पदोन्नति भई पोखराको पृथ्वनारायण क्याम्पसमा सरुवा हुनुपच्यो। त्यसको केही वर्षपछि, उनको सरुवा विराटनगर महेन्द्र आदर्श ब. क्या.मा भयो। पछि, पुन: २०४२ सालमा धनकुटामा नै सरुवा भएपछि चाहि उनको स्थायी बसोबास धनकुटामा नै हुनपुग्यो। प्राध्यपन गर्दे जाँदा २०४ रा४३ सालमा प्रशासनिक नेतृत्त्व समेत सम्हाल्नु पर्ने स्थिति आइपर्दा उनी यसै क्याम्पसका प्रमुख पनि भए । पछि २०पू सालमा सहप्राध्यापक पदबाट अनिवार्य अवकाश प्राप्तगरेका यिनले थप १०।११ वर्षसम्म महेश संस्कृत गुरुकुल देवघाट, तनहुँमा अध्यापन गरे । यसरी यिनले विद्यालय तहदेखि विश्वविद्यालय तहसम्म र गुरुकुलमा समेत गर्दा पू६। पू७ वर्षसम्म अध्यापन गरेको देखिन्छ। यो अवधि हेर्दा उनले आफ्नो समग्र आयुको दुई तिहाइभन्दा बढी नै अवधि औपचारिक रूपमा शिक्षा शिक्षण गर्ने ऋममा नै व्यतीत गरेको देखिन्छ।

बाल्यकालमा नै अध्ययनका लागि वनारस पुगेका कृष्णप्रसादले त्यहाँको साहित्यिक वातावरणसंग परिचित हुने मौका पाए। त्यहाँका सामाजिक-सांस्कृतिक, भौगोलिक परिवेश, साथीभाइहरूसँगको सझुत, विद्यालयका साहित्यिक कार्यक्रमहरू, गुरुहरूको प्रेरणा-प्रभाव इत्यादिबाट उनलाई पनि कविता लेखनको प्रेरणा जागृत भएको देखिन्छ। त्यसको प्रतिफल उनले २०१४ सालमा भ्याउरे भाकामा कवितामा चिठी लेखेर नेपाल घरमा पठाइएको देखिन्छ :-

पौषको सत्र लेखेको पत्र चौबीस गतेमा ।

पाएर हेर्दा आनन्द लाग्यो लिएर हातमा॥

दु:खको बादल हटाई सारा हर्षका चन्द्रमा।

उदाए उज्ज्वल फिंजाए शोभा .मनका व्योममा॥

यसरी प्रस्फुटन भएको उनको कवित्त्वले विकसित हुँदैजाने अवसरहरू प्राप्तगर्दे जाँदा २०४० को दशकदेखि बाक्लै रूपमा कृति लेखन, प्रकाशन गर्न थालेको देखिन्छ र यो क्रम २०७० को दशकसम्म नै कायम रहेको देखिन्छ। यस ऋममा देखिएका उनका प्रकाशित कृतिहरूमा विश्रान्ति पुष्पाज्जली (२०४१) देवभजन सड्ग्रह, वाणीस्मरण (२०६०) समीक्षात्मक लेख सड्ग्रह, वणीवन्दना (२०६४) कविता सड्ग्रह, नरहरि (२०६३), ठूलीआमा (२०६३), शक्तिमाता (२०६३), कृष्णराज (२०६४), युवराज (२०६४) खण्डकाव्यहरू र वैदिक सनानन्त धर्म (२०६४) 
गद्य सड्ग्रह, वस्ती वंशावली (फलाँटेतर्फ, २०६१) रहेका छन् । त्यस्तै अप्रकाशित कृतिहरूमा आचार्य तुलसी जीवनगाथा (अनुवाद,२०४३), जीवनगाथा आशीर्वाद (२०६२), भोजपुरदेखि भरतपुरसम्म (२०६४), जीवनदर्पण (२०६४), दलबहादुर (२०६५), भक्तबहादुर कर्णेल (धनकुटाका दानवीर) (२०६६), पादाम्बुजपूजा (२०६७), नार दसन्तति (२०७०) खण्डकाव्य र आजै बिलायौ तिमी (२०७०) शोककाव्य, जीवनपथ (२०७०) स्मृतिकाव्य रहेका छन् । यसरी यिनका एक भजन सड्ग्रह, एक समीक्षात्मक लेख सड्ग्रह, एक कविता सड्ग्रह, एक गद्य सड्ग्रह, एक वंशावाली र पाँच खण्डकाव्य र एक अनुदित कृति प्रकाशित भएका छन् । त्यस्तै यिनका $\vartheta$ ओटा खण्डकाव्य, एक शोककाव्य र एक स्मृतिकाव्य भने छुटै पुस्तकाकारमा प्रकाशित नभए पनि उनकै स्मृतिग्रन्थमा सड्गृहीत गरिएका छन् ।

\section{'दलबहादुर' खण्डकाव्यको कथावस्तु}

'दलबहादुर' खण्डकाव्यका नायक दलबहादुरले तत्कालीन समय परिस्थिति अनुसार पहिलो विवाह गरे । उनीबाट एक छोरा जन्मिए। तिनको नाम फौदसिंह हो। पछि, उनीहरूको घर हुन सकेन। पत्नीले उनलाई छाडेर अर्को विवाह गरिन् । दलले पनि दोस्रो विवाह गरे । उनको हराएको घरको शोभामा पुन: नयाँ पाउला पलाउन थाल्यो । नववधूले पहिली पत्नीबाट जन्मिएको पुत्ररत्न फौदसिंहलाई हुर्काउदै थिइन् । आफ्ना सन्तान भएका थिएनन्। दैवले उनीहरूको माया, प्रेम देख्न सकेन कि क्या हो ! उनकी दोस्री पत्नीको पनि निधन भयो। पत्नीको काजक्रिया सकेपछि जेठी पटिको छोरो फौदको ब्रतबन्ध गरे । त्यसैताका उनकी आमाको पनि निधन भयो। आमाको काजकृया सकेपछि बालक छोरालाई समेत एक्लै छाडेर उनी गृहस्थी जीवनबाट विराक्तएर घरछोडी हिंडे। भारतका अनेक मठमन्दिरका साधुसन्तहरूसँग सत्संगत गर्दै साधु बनेर रहनथाले। घर,सन्तानको मायामोह त्यागे।

त्यस्तै समयमा बर्षेनी हिँदमा भारतका विभिन्न तीर्थ स्थलमा तीर्थाटन गर्न जने फलाँटेकै कोही तीर्थयात्री बन्धुले उनलाई भेटेर घर फर्काई ल्याए। गाउँसमाजले मिलेर उनलाई पुन : विवाह गराइदियो। अब उनको तेस्रो विवाह भयो । तेस्री पत्नीबाट यिनलाई एक छोरी र तीन छोरा प्राप्त भए। पहिली पाटिका छोराको पनि विवाह भयो। घर गृहस्थी निकै फलिफाव हुँदै गयो। छोरीको पनि विवाह भयो। पछि उनी पहाड छोडी सुनसरीको बंकलुवामा बसोबास गर्न थाले। त्यस समयमा उनको घरजगगा, गाईगोठ इत्यादिको कारोवार पनि निकै फस्टाएर गयो। तर यहाँ पनि मधेशको घामपानी सहन नसकी वा के भएर हो, उनकी तेश्री श्रीमतीको पनि निधन भई उनलाई अर्को विपत्ति आइलाग्यो। केही समयपछि त्यहाँका पनि गाउँलेहरूले मिलेर उनको विवाह गराए। अब उनको चौथो विवाह भयो। त्यतापटिबाट पनि उनलाई दुई पुत्ररत्न प्राप्त भयो। त्यस बखतमा पनि उनले पहिलेको वैंशको बेलाको जस्तै तुजुक देखाउँदै बसाइँ सरेर रामधुनी आसपासको मानपुर भन्ने ठाउँमा गए। पाको उमेर, वृद्ध शरीर भएकाले केही कालपछि पछि, उनको त्यहीं देहावसान भयो। पछि उनकी छारीको अनुरोधमा अन्य सन्तान, इष्टमित्र,बन्धुवर्गादि मिलेर उनको दिवंगत आत्माको मुक्तिका निमित्त श्रीमद्भागवत सप्ताह ज्ञान महायज्ञ लगाएको प्रसझ र भागवतको महिमा वर्णनसहित कथानकको अन्त्य भएको छ।)

\section{'दलबहादुर' खण्डकाव्यका मुख्य विशेषताहरू}

- सामाजिक विषयवस्तुमा आधारित करुण रस प्रधान वियोगात्मक काव्य,

- सामान्य ग्रामीण पाहाडिया व्यक्ति दलबहादुरलाई नायक बनाई उसकै जीवन चरित्र प्रस्तुत गरिएको काव्य,

- काव्य नायकले जीवनमा केल्नु परेका अनेकन सुख दुखात्मक क्षणहरूको वर्णन भएको काव्य,

- सहज सरल प्रस्तुतिभित्र पनि पूर्वीय काव्यशास्त्रीय मान्यताको अनुशरण गरी रचना गरिएको काव्य,

- तीन सर्गभित्र (शार्दूलविक्रीडित, मन्दाकान्ता, शिखरिणी र अनुष्टुप छन्दका) २६० श्लोकमा संरचित काव्य, 
- अनेक अलङ्कारले युक्त नायक प्रधान काव्य,

- पूर्वी पहाडी जिल्ला धनकुटाको फलाँटे गाउँको सेरोफेरो र तराईको सुनसरी जिल्लाको इनरुवा र रामधुनी आसपासको परिवेश प्रस्तुत गरिएको काव्य ।

\section{अध्ययन विधि}

यो लेख तयार गर्दाका सम्पूर्ण अध्ययन सामग्रीहरू द्वितीय स्रोतमा आधारित रहेका छन् । 'पण्डित कृष्णप्रसाद 'शर्मा वस्ती स्मृतिग्रन्थ', यसैभित्र समेटिएको 'दलबहादुर' खण्डकाव्य र त्यसका बारेमा त्यही ग्रन्थमा लेखक तथा सम्पादकले प्रस्तुत गरेका टिपोट, लेख रचनादिका साथै अलड्कारसम्बन्धीका शास्त्रीय ग्रन्थ एवं समालोचनाका पुस्तक, शब्दकोश आदि यो लेख निर्माणका सामग्री हुन् । ती सड्कलित सामग्रीहरूलाई परिरचय, परिणम र छलफल जस्ता उपशीर्षकहरूमा वर्गीकरण गरी अध्ययन गरिएको छ। यिनै सामग्रीहरूको अध्ययन विश्लेषण गर्दे विवरणात्मक र वर्णनात्मक ढाँचामा यो लेख तयार पारिएको छ।

\section{परिणाम र छलफल}

यस लेखमा खण्डकाव्यकार कृष्णप्रसाद वस्तीको सझ्क्षिप्त जीवनी, कृतिहरूको विवरण,'दलबहादुर' खण्डकाव्यको कथावस्तु, विशेषता र यस खण्डकाव्यमा विधान गरिएका मुख्य-मुख्य अलड्कारहरूको सैद्धान्तिक लक्षण परिचय सहित प्रयोगात्मक पक्षको वर्णन, विश्लेषणका सम्बन्धमा छलफल गरिएको छ। यस छलफलबाट काव्यकारको व्यक्तित्व र कृतित्वको सड़क्षिप्त परिचय, 'दलबहादुर' खण्डकाव्यको कथावस्तु, विशेषता र यस काव्यमा विधान गरिएका $\checkmark$ ओटा शब्दालड्कार र $q$ ओटा अर्थालड्कारको प्रयोग स्थितिको वर्णन, विश्लेषण सहित निष्कर्ष प्रस्तुत गर्नु नै यस लेखको परिणाम हो ।

\section{अलड्कारको परिचय}

अलड़कार शब्द संस्कृत शब्द हो । संस्कृत व्याकरण अनुसार अलम् + कृ + घन् (अ) को योगबाट निर्माणहुने यस शब्दको अर्थ श्रृड्गार सामग्री, सजावट, गहना, आभूषणादि भन्ने हुन्छ। साहित्यिक अर्थमा शब्दगत र अर्थगत चमत्कार उत्पन्न गराउने तत्त्व नै अलड्कार हो। छोटकरीमा भन्दा कविताकाव्यमा सौन्दर्य सिर्जना गर्नका लागि अपनाइने चमत्कारयुक्त वर्णनशैली नै अलड्कार हो। यसका मुख्य रूपमा शब्दालड्कार, अर्थालड्कार र उभयालड्कार गरी तीन भेदहरू छन् ।

शब्दालङ्कारः कविताकाव्य वा साहित्यको सौन्दर्य शब्द विशेषबाट अभिव्यक्त गरिएमा शब्दालङ्कार हुन्छ। यस्तो अलड्कारको प्रयोगमा पर्यायवाची शब्दको प्रयोग गर्न मिल्दैन ।

अर्थालड्कारः कविताकाव्य वा साहित्यको सौन्दर्य शब्दको अर्थ विशेषमा आश्रित हुने अलड्कारलाई अर्थालड्कार भनिन्छ। यसमा पर्यायवाची शब्दको प्रयोग गर्न पनि सकिन्छ।

उभयालङ्कारः कविताकाव्य वा साहित्यिक रचनामा शब्दालड्कार र अर्थालड्कार दुवै एकै ठाउँमा प्रयोग भई सौन्दर्य सृजना भएमा उभयालड्कार हुन्छ।

\section{'दलबहादुर' खण्डकाव्यमा विधान गरिएका केही शब्दालङ्कारहरू छेकानुप्रासः}

लक्षण : स्वर-व्यज्जन-सन्दोह-व्यूहा-मन्दोहदोहदा ।

गौर्जगज्जाग्रदुत्सेका छेकानुप्रासभासुरा |४|२। (जयदेव : ५०)

अर्थात् जहाँ अनेक स्वर वा व्यन्जन वर्णहरूको एकपटक मात्र आवृत्ति भई श्रुतिमाधुर्यता उत्पन्न भएमा छेकानुप्रास शब्दालड्कार हुन्छ। 
कृष्णगोविन्द अधिकारी/ 'दलबहादुर' खण्डकाव्यमा....

कार्कीमा गजवीर एक चिनिने त्यो गाउँमा बस्तथे,

जान्थे जागिरमा घुमेर घरमा आई छिंटै पस्दथे ॥९९॥ (प्रथम सर्ग, पृ.ढ१४)

यहाँ गाउँमा, गजवीर जान्थे जागिरमा घुमेर घरमा जस्ता शब्दहरूमा ग, ज, घ,व्यञ्जन वर्णहरूको आवृत्ति एक एक पटक मात्र भएको हुँदा छेकानुप्रास अलङ्कार छ।

\section{वृत्त्यानुप्रास:}

लक्षण : आवृत्तवर्णसम्पूर्ण वृत्त्यनुप्रासवदूचः |४|३| (जयदेव : ५१)

अर्थात् जहाँ एक वा अनेक वर्णहरूको अनेकपटक आवृत्ति भई श्रुतिमाधुर्यता उत्पन्न भएमा वृत्त्यानुप्रास शब्दालड्कार हुन्छ।

जाओस् बाबु जतासुकै बरु यहाँ आमा थियो चाहिने

खप्नै पर्दछ दैवको खटन हो जे जे जहाँ गर्दछ ॥४९॥ (प्र.स., पृ.५२१)

यहाँ 'ज' र 'क’ व्यज्जन वर्णको अनेक पटक आवृत्ति भएको हुँदा वृत्त्यानुप्रास अलड्कार छ।

\section{श्रुत्यनुप्रास}

लक्षण : उच्चार्यत्वाद्यदेकत्र स्थाने तालुरदादिके

सादृश्यं व्यज्जनकस्यैव श्रुत्यनुप्रास उच्यते ॥१०।॥॥ (विश्वनाथ : ६१२)

अर्थात् कुनै एउटै उच्चारण स्थानबाट उच्चारित हुने एक वा अनेक व्यज्जन वर्णहरूको आवृत्ति हुँदा उत्पन्न हुने श्रुतिमाधुर्यता नै श्रुत्यनुप्रास शब्दालड्कार हो ।

थियो केरावारी घरमुनि हुने वृक्ष खयर,

कतै काँडाघारी वर पर हुने धेर बयर।

हुने गाई भैंसी अधम चितुवाको पनि भय,

परे मौका खेदी परपर लगी गई विजय ॥४०॥ (द्वितीय सर्ग, पृ.५२९)

यहाँ काव्यनायकको पहाडको घर वरिपरिको परिवेशको वर्णन छ। जसमा घरमुनिको केराको क्याइ र खयरको रूख, काँडाघारी, त्यसका वरपर हुने बयरका बुट्यान,आसपासको गाईभैंसीको गोठ अनि त्यहाँ मौका पार्न सकेमा चितुवाले शिकार गरी विजय प्राप्त गर्ने कुराको वर्णन गर्दा आएका शब्दहरूमा एउटै कण्ठ स्थानबाट उच्चारित हुने क, ख, ग, घ, ह जस्ता व्यञ्जन वर्णहरू आएकाले श्रुत्यनुप्रास अलड्कार छ।

\section{अन्त्यानुप्रास}

लक्षण : व्यज्जनं चेद्यथावस्थं सहाहैन स्वरेण तु ।

आवर्त्यतेऽन्त्ययोज्यत्वादन्त्यानुप्रास एव तत् ॥१०६६॥ (विश्वनाथ : ६१३)

अर्थात् जहाँ स्वरकासाथ अनुस्वार, विसर्ग र स्वरले युक्त व्यज्जन वर्ण वा शब्द नै कविताका श्लोकका विभिन्न पाउहरूमा आवृत्ति भई श्रुतिमाधुर्यता उत्पन्न गराएमा अन्त्यानुप्रास शब्दालड्कार हुन्छ।

आई मत्स्य वराह कूर्म हरिले लीला गरेको कति, खाँबामा नरसिंह वामन हुँदै आँखा तरको अति । खेलेको वलराम राम कहिले भूलोकमा पाइने, सुन्दा दिव्य कथा सधैं मन दिई वैकुण्ठमा जाइने ॥४६॥ (तृ.स., पृ. ५४७) 
श्रीमद्भागवत महापुराणको गरिमा, महिमासहित भगवान्का दश अवतारको वर्णन गरिएको यस श्लोकका प्रत्येक पाउका अन्त्यमा कति-अति, पाइने-जाइने जस्ता तुकबन्दियुक्त शब्दहरूको प्रयोग भएको हुँदा, यहाँ अन्यानुप्रास शब्दालड्कार छ।

\section{'दलबहादुर' खण्डकाव्यमा विधान गरिएका मुख्य अर्थालङ्कारहरू काव्यलिज्ञ}

लक्षण : काव्यलिड्ग हेतोर्वाक्यपदार्थता ॥१०, सूत्र, १७३॥१०११९४। (मम्मट : ४१०)

अर्थात् कारणलाई वाक्यार्थ वा पदार्थका रूपमा प्रयोग गर्दा काव्यलिड़्ग अलड्कार हुन्छ।

खेती गर्न र वस्तु पाल्न गतिलो त्यो गाउँ नामी थियो, पानी चाहिं थिएन दूर छ कुवा हैरान धेरै थियो ।

चल्दा जाँगर जोडिएछ कतिको खेती तराईतिर,

औलाको तर धेरनै भय हुँदा पार्थे अँध्यारा शिर ॥१७॥ (प्रथम सर्ग, पृ. द१४)

यहाँ, तराईमा खेती जोड्ने कारण जाँगर र शिर अँध्यारो पार्ने कारण चाहिँ तराईमा औलो रोगको भय थियो भन्ने कुरा वर्णन गरिएको हुँदा काव्यलिड़ अलड्कार छ।

\section{दृष्टान्त}

लक्षण : चेद् बिम्बप्रतिबिम्बत्वं दृष्टान्तस्तदलङ्कृतिः ॥ भ। पू६॥ (जयदेव : १३२)

अर्थात् उपमान र उपमेयका बीचमा बिम्ब, प्रतिबिम्ब भाव उत्पन्न भएमा दृष्टान्त अलड्कार हुन्छ।

जाउँ लौ त लुगा फुकाल अघिका फेरेर आफ्ना घर,

छोडी सड्गत साधुको अब छिटो मानेर हाम्रो भर ।

हेर्थे साधु समाजतर्फ तर ती ताने समाती यता,

माछो जाल लिएर जान कसरी भागेर सक्थ्यो कता ॥७॥ (द्वितीय सर्ग, पृ.द२४)

यहाँ, वैरागी भई घरबाट भागेर हिंडेका नायक दलबहादुरलाई बैरै वर्षपछि आफ़नै गाउँका कुनै तीर्थयात्रु बन्धुले भारतको कुनै तीर्थमा साधुका मण्डलीमा देख्दछ् र चिनेर एकान्तमा बोलाई गफ गरेको प्रसड़ छ। त्यही ऋममा ती गाउँले तीर्थयात्रीले दलबहादुरलाई साधुको भेष बदली अर्के लुगा फेरेर आफ़नै गाउँमा हिंड भन्दा उनले आफ्नो साधुमण्डली तिर हेरेर उतै जान खोजेका छन्। तर उसलाई आफ्नै घरतिर फर्काइएको कुरालाई जालमा फसिसकेको माछो जाल सहित उम्केर आफ्नै स्थानमा किन जान सक्यो, ऊ त माकीकै खटनको हुन्छ भनी यहाँ वर्णन गरिएको हुँदा उपमेय, तीर्थयात्री बन्धुले तानिएको दलबहादुर र उपमान जालभित्र फसेको माछोका बीच बिम्ब, प्रतिबिम्ब भाव प्रस्तुत भएको हँदा दृष्टान्त अलड्कार छ।

\section{रूपक}

लक्षण : तद्रूपकमभेदो य उपमानोपमेययो: ॥१०, सूत्र १३६॥ (मम्मट : ४६३)

अर्थात् उपपमान र उपमेयको अभेद वर्णन भएमा रूपक अलड्कार हुन्छ। अथवा उपमान र उपमेय भिन्न भिन्न वस्तु हुँदाहुँदै पनि उपमेयमा नै उपमानलाई अभेद रूपमा आरोप गरेर वर्णन गरेमा रूपक हुन्छ।

त्यस्तो स्वर्ग समान कर्भर जहाँ खुल्थ्यो नयाँ यौवन, काला केश ललाट उच्च भरिला गाला मिलेका तन । ज्वालाभित्र परी उडेर क्षणमा हेर्दा खरानी भयो, शोभा जो घरको सुरत्न दलको सर्वस्व छोडी गयो ॥४४॥ (तृतीय सर्ग, पृ. ५१९) 
यहाँ काला केश, उच्च ललाट, भरिला गाला र मिलेको शरीर भएकी सुन्दर नवयौवना दलबहादुरकी श्रीमती (उपमेय)लाई चिताको ज्वालाले क्षणभरमा नै खरानी तुल्यायो। अब दलबहादुरको सुरत्न र घरको शोभा सबै सकियो भन्ने प्रसड़्ग यहाँ व्यक्त भएको छ। यहाँ दलबहादुरकी श्रीमती (उपमेय)लाई घरको शोभा र दलबहादुरको सुरत्न (उपमान)का रूपमा आरोप गरिएको हुँदा रूपक अलड्कार छ।

\section{समुच्चय}

लक्षण : तत्सिद्विहेतावेकस्मिन् यत्रान्यत् तत्करं भवेत् । समुच्चयोडसौ॥ १०, सूत्र १७७॥ (मम्मट : प११५) अर्थात् कुनै कार्यसिद्धिका लागि एउटैमात्र कारण पर्याप्त हुदाँहुँदै पानि अन्य धेरै कारणहरू समेत साधकका रूपमा प्रस्तुत भएमा समुच्चय अलड्कार हुन्छ।

केही काल बित्यो यसै तरहले नारी हुँदाको घर, बेग्लै हुन्छ सह्यार पुगछ घरको मान्छन् सबैले भर । पत्नीका गुण, रूप, शील, मतिले आनन्द मान्थे पति, सेवा बालक वृद्धको पनि हुँदा बस्थे रमाई अति ॥३६॥ (प्र.स., पृ.द१७)

यस वर्णनमा दलबहादुरका निम्ति उनकी दोस्री पत्नीमा विद्यमान रहेका गुण, रूप, शील,मति मध्ये एउटै गुण मात्र पनि पर्याप्त थियो तर यहाँ त गुण,शील,मति जस्ता सबै विशेषताहरू त्यही गुणका थप साधनभूत भएर प्रस्तुत भएका हुँदा समुच्चय अलड़कार छ।

\section{विशेषोक्ति}

लक्षण : विशेषोक्तिरखण्डेषु कारणेषुफलावचः ॥ १०, सूत्र १६२ ॥ (मम्मट : ४९६)

अर्थात् फल प्राप्तिका निमित्त आवश्यक पर्याप्त कारणहरू हुँदा हुँदै पनि कार्योत्पत्ति (फलप्राप्ति) नभएको वर्णन भएमा विशेषोक्ति अलड्कार हुन्छ।

भान्सादेखि लिएर काम घरको जे पई गर्दे थिइन्, एकाएक भएर के दिन कुनै पत्नी बिरामी भइन् ।

धामी औषधि पाइने जरिबुटी भेटे सकेको गरे,

केही न्यून भएन रोग उनको ज्यादै विपत्मा परे ॥४०॥ (प्र.स., पृ.५१६)

यहाँ काव्यनायककी दोसी पत्नीले परिवारको राम्रोसँग ख्याल गरी घरगृहस्थी सन्चालनमा महत्त्वपूर्ण योगदान पुच्याइरहेका बखतमा उनी अचानक बिमारी परिन्। धामीभाँक्री, जराबुटा सहित अनेक औषधीमूलो गर्दा पनि उनको रोग निको नभएकाले परिवार विपत्तिमा पर्दे गएको वर्णन छ। यहाँ बिरामी भएका मानिसलाई निको पार्नका लागि तत्कालीन समयमा प्रचलित सम्पूर्ण उपायहरू गर्दा पनि बिराम निकोहुन सकेको छै। । अतः यहाँ अनेक कारणहरू प्रस्तुत हुँदहहुँदै पनि कार्योत्पत्ति नभएको वर्णन भएकाले विशेषोक्ति अलड्कार छ।

\section{स्मरण}

लक्षण : वस्तुविशेषं दृष्ट्वा प्रतिपत्ता स्मरति यत्र तत्सदृशम्

कालान्तरानुभूतं वस्त्वन्तरमित्यद: स्मरणम् ॥५॥१०९॥ (रुद्रट : ३०१)

अर्थात् प्रत्यक्ष रूपमा देखिएको वा अनुभव गरिएको वस्तुबाट तत्सदृश अप्रत्यक्ष वस्तुको स्मरण भएमा स्मरण अलझ्रकार हुन्छ।

आमाको दश गात्र कर्म सकियो बाटो सबैले लिए,

त्यो बेला बहिनी र जो अरू यहाँ आई रहेका थिए। 
छैनन् मानिस बोल्नसम्म घरमा छन् बाबु छोरा अब, सम्भिन्छन् अघिका विचित्र घटना जे जे घटेथे सब ॥४६॥ (प्र.स.,प्. द१९)

यहाँ काव्य नायक दलकी दोसी पत्नीको मृत्यु भइसकेको केही समयपछि, उनकी आमाको पनि मृत्यु भएर दशगात्र कर्म सकिएको छ। दशगात्र कर्ममा भेला भएका आफन्तजनहरू, नाता, कुटुम्ब, बहिनीहरू सबै बिदावारी भई दलका घरबाट हिंडिसकेका छन् । उनका साथमा अब एक अबोध शिशु छोरो (५-६ वर्ष जतिको) मात्र छ। यस अवस्थामा घरमा बोल्नेसम्म मानिस नहुँदाको अवस्थाले उनलाई विगतका आफ्ना जीवनमा घटेका सुख, दु:खका विचित्र घटनाहरूको स्मरण भएकाले यहाँ स्मरण अलड्कार छ।

\section{उदात्त}

लक्षण : उदात्तं वस्तुन: सम्पत् । महतां चोपलक्षणम् ॥१०,सूत्र, १७४,१७६।,१९०११४। (मम्मट : ४१९४)

अर्थात् महान् व्यक्तिको चरित्र वर्णनमा उदात्त अलङ्कार हुन्छ। त्यस्तै धन, सम्पत्ति, वैभवादि, महान्कार्य र गरिमा, महिमादिको वर्णनमा पनि उदात्त अलङ्कार हुन्छ।

आस्था वैदिक धर्ममा दृढ थियो मान्थे बढ़ी ईश्वर, आफ्ना पूर्वजको र मान्यजनको गर्थे सधैं आदर। कार्की वंश र गाउँका मणि थिए गर्थे सबैको हित, छैनन् ती घरमा गए अब कता सोधौं कहाँ को सित ॥४६॥ (प्र.स., पृ.द२२)

यहाँ, नयक दलबहादुरका महान् कार्यको वर्णन गरिएको छ। उनी वैदिक सनातन धर्ममा दृढ भई ईश्वर मान्दथे, आफ्ना पूर्वज र मान्यजनको आदर गर्दथे। कार्की वंशका कुलमणि मात्र नभई सबै गाउँकै हीत गर्ने यस्ता महान् व्यक्ति आज घरमा छैनन्। कहाँ गए कता गए कसलाई सोधौं भनी महान् व्यक्तित्वका धनी दलबहादुरको स्मरण गरिएको हुँदा उदात्त अलड्कार छ।

\section{उपमा}

लक्षण : साम्यंवाच्यमवैधर्म्यं वाक्यैकमुपमादूयो: ॥१०१९४॥ (विश्वनाथ : ६४२)

अर्थात् समान धर्म भएका अलग अलग वस्तु उपमान र उपमेका बीचको सादृश्यतालाई एकै ठाउँमा वर्णन गरेमा उपमा अलड्कार हुन्छ।

आयो त्यो दिन घोर मानुपुरमा टारेर टर्थ्यो किन,

देखी आयु भएछ शेष दलको भन्ने जनाई लिन ।

जाँदा प्राण ढल्यो शरीर जसरी त्यो काटिएको रूख,

हाहाकार गरी रुने सब भए भागी हरायो सुख ॥३१॥ (तृ.स., पृ.ॅ૪३)

बंकलुवाबाट मानपुरमा बसाइँ सरी आएका दलबहादुरका जीवनमा घोर दु:ख आइपयो, जुन कुरा टारेर टार्न सकिने पनि होइन। उनकै आयु सकिएर प्राण ढल्यो जसरी कटेको वृक्ष ढल्दछ। परिवारमा हाहाकार भयो, घरको सुख सबै हरायो भन्ने भाव वर्णन गरिएको यस श्लोकमा उपमा अलङ्कार छ। यहाँ दलबहादुरको शरीर ढल्नु (प्राण जानु) उपमेय हो भने काटिएको रूख उपमान हो। यहाँ उपमान र उपमेय दुई अलग वस्तुको समान धर्म ढल्नु रहेको छ भने सादृश्यवाचक शब्द, जसरी आएको हुँदा यहाँ पूर्णोपमा अलड्कार छ।

\section{अतिशयोक्ति}

लक्षण : निगीर्याध्यवसानन्तु प्रकृतस्य परेण यत् । (१०, सूत्र १२२)

प्रस्तुतस्य यदन्यत्वं यद्यर्थोक्तौ च कल्पनम् ॥१०१९०॥ (मम्मट : ४५२) 
अर्थात् उपमानले उपमेयलाई आफूभित्र निगीरण (समाहित वा निलेर)गरी अभेद रूपमा आफूमात्र (उपमान मात्रै) प्रकटीकृत भएर प्रस्तुत (उपमेय)लाई भिन्नै किसिमले वर्णन गर्दा अतिशयोक्ति अलङ्कार हुन्छ। उपमानले उपमेयको निगीरण गरी उपमान आफ़ मात्रै प्रस्तुत र उपमेय अदृश्य हुँदा अतिशयोक्ति अलङ्कार हुन्छ।

सोचेरै हित मित्र बधुजनले ल्याए मलाई यता,

भेटेका नभए त्यहाँ समयमा पुग्थँ म होला कता ।

साड्लाले सब बाँधिए म सुनका गाँठो नफुक्ने गरी,

जो होला अब भोलि पई्छ सहनै जो आउने हो परी ॥२३॥ (द्वि.स., पृ.द२६)

यहाँ गाउँले तीर्थयात्रु बन्धुजनले हित सोचेर नै वैरागी भएका दलबहादुरलाई घर गृहस्थीमा फर्काएर कहिल्यै नखुस्किने गरी गृहस्थीका सुनका साङ्लाले बाँधे। अब भविष्यमा जे-जस्ता सुख, दु:खहरू आइपर्छन् ती सबै सहनै पर्ने भो भन्ने भनाइ व्यक्त भएको छ। यहाँ गृहस्थी जीवनमा फर्किएर पत्नीका साथमा दलबहादुरले व्यतित गरेको सौन्दर्यमय व्यवहार उपमेयलाई सुनको साङ्लो उपमानले आफ़भित्रै निगीरण (समाविष्ट) गरी प्रस्तुत भएको हुँदा अतिशयोक्ति अलङ्कार छ।

\section{अर्थान्तरन्यास}

लक्षण : सामान्यं वा विशेषो वा तदन्येन समर्थ्यते ॥१०, सूत्र १६४॥

यत्तु सोऽर्थान्तरन्यास: साधर्म्येणेतरेण वा ॥१०॥१०९॥ (मम्मट : प००)

अर्थात् सामान्य भनाइलाई विशेष भनाइले वा विशेष भनाइलाई सामान्य भनाइले समर्थन गरी वर्णन गरेमा अर्थान्तरन्यास अलड्कार हुन्छ। विशेषतः यसमा मुख्य अर्थसँग मिल्दोजुल्दो कुनै दोस्रो अर्थको कथन गरिएको हुन्छ।

देख्दा त्यो पतिको दशा दिनदिनै पत्नी डुबिन् शोकमा,

को पो जन्म लिएर हुन्छ रहने बाँचेर यो लोकमा ।

आमा बाबु गए कुनै अघि भए आफ्ना भनेका जन,

आएथे जसरी गए पनि उतै केही नबोकी धन ॥३०॥ (तृ.स.,पृ.५ ३३)

यहाँ दलबहादुरको निधन भइसकेको छ। बाँचेकी कान्छी श्रीमती शोकमा छिन् । जेठी र साइली श्रीमतीका छोराहरूले आमाबाबु दुबै र कान्छीका छोराहरूले बाबुको मरण भएको कुरालाई अभिव्यक्त गरिरहेका छन्। यो अभिव्यक्तिमा संसारमा जन्म लिएको को पो व्यक्ति संधै बाँच्ने हुन्छन् र ! भन्ने सामान्य कथनलाई जन्मदा जसरी रित्तो हात आएका थिए त्यसरी नै केही धन नबोकी रित्तै हात गए भन्ने विशेष कथनले समर्थन गरेको हुँदा अर्थान्तरन्यास अलङ्कार छ।

\section{उत्प्रेक्षा}

लक्षण : सम्भावनमथोत्प्रेक्षा प्रकृतस्य समेन यत् ॥१०, सूत्र १३६॥ (मम्मट : ४६०)

अर्थात् प्रकृत (वर्णनीय विषय उपमेयलाई) सम (उपमान)का साथ सम्भावना गरी वर्णन गरेमा उत्प्रेक्षा अलड्कार हुन्छ। अथवा उपमेय नै उपमान हो कि भनी सन्देह वा सम्भावना प्रस्तुत गरेमा उत्प्रेक्षा अलङ्कार हुन्छ।

छोडी चट्टै घर किन यहाँ ठाउँ अन्यत्र लागे,

घुम्दै जाँदा अलिकति कुनै ठाउँमा बास मागे ।

छैनन् आफ्ना जन भर दिने दु:खले फेरि घेचो,

के ले यस्तो मति हुन गयो राहुले पो कि हेच्यो ॥२३॥ (तृ.स., प..५४१) 
यहाँ तेस्री श्रमितीसँगको विवाह पश्चात् जन्मिएका चार सन्ततिको उज्ज्वल भविष्य पहाडको फलाँटेमा मात्र बसिरहेर सम्भव छैन भनी तराई भरेर सुनसरीको बंकलुवा(सुनसरी नदीको किनारतिरको स्थल)मा राम्र उन्नति प्रगति गरी सम्पन्नताका साथ बसेका दलबहादुरकी श्रीमतीको देहान्त भयो। त्यसबाट उनको पारिवारिक जीवनमा ठूलो विचल्ली भयो। त्यहाँ पनि गाउँलेको अनुरोधलाई स्वीकारेर उनले चौथो विवाह गरे । यो विवाह असहज पनि थियो तर पनि उनको जीवनमा केही शीतलता त आयो। उनको उमेर ढिल्कएकै हो तर फेरि उनको काम गर्ने, व्यवहार गर्ने तरिका चाहि उमेरमा तुजुक देखाएर जस्तै थियो। त्यसैले उनी त्यस अवस्थमा पनि त्यो ठाउँ चटक्कै छोडेर रामधुनीका आसपासको मानपुर भन्ने ठाउँमा बसाइँ सरेको अवस्थालाई वर्णन गरिएको छ। त्यस नयाँ ठाउँमा उनका आफन्तजन कोही छैनन् । सम्पूर्ण कुराहरूको चाँजोपाँजो आफै (वृद्ध)ले नै गर्नु परेको स्थितिलाई देखेर कविले वर्णन गर्दा यी दलबहादुर (उपमेय)को बुद्धि के पो हुन गयो ! राहु (उपमान)का ग्रहले पिरोलेर वा राहु लागेर यी पनि राहु जस्तै अरूलाई पिरोल्ने पो हुनलागे कि, के हो! भनी उपमेयमा उपमानको आशंका गरिएको हुँदा उत्प्रेक्षा अलड्कार छ।

\section{अर्थापत्ति}

लक्षण : अर्थापत्ति स्वयं सिध्येत् पदार्थान्तरवर्णनम् ॥५/३७॥ (जयदेव : १९४)

अर्थात् एउटा किसिमको वर्णनबाट अर्को कुराको स्वतः सिद्धि भएमा अर्थापत्ति अलड्कार हुन्छ । यो अलड्कारका सम्बन्धमा दण्डापुपिकान्याय (दण्ड+अपूपिका+न्याय = मुसाले अपुड्ग्गो बाँधेर राखेको लौरो समेत त खाइसक्यो भने त्यसमा बाँधेको अपुड़ो कसरी बाँकी राख्यो त) र कौमुत्यन्याय (कसैले महान् कार्य नै सम्पन्न गरिसकेको छ भने उसका लागि साना तिना कार्य सम्पन्न गर्न त के असहजता हुन्छ र ! भन्ने सिद्धान्तका आधारमा यो अलड़कारको आविर्भाव गरिएको प्रसड़्र उल्लेख गरेका छन् (निरौला : २३४)।

जुम्रा धेरै कपालमा कति परे सतै लिखा टल्किने,

आँखाभित्र गुफा समान जसको छाति करड भल्किने ।

खानै पाउनु छैन पेट भरने शिक्षा लिने के अनि,

पापी निर्धनता छ शत्रु सबको मर्दैन मारे पनि ॥२७॥ (द्वि.स., पृ. द२७)

यहाँ वैरागी बनेर घर छोडी हिंडेका दलबहादुरलाई गाउँले बन्धुले खोजेर गाउँमा ल्याई तेस्रो विवाह गराइदिएका हुन्। ती नवविवाहिता पत्नीले विवाह गरेर आफू आएको गाउँको समाजको चालचलन, रहनसहन, वस्तुस्थिति हेरेने, मनन गर्ने कममा प्रस्तुत अभिव्यक्ति व्यक्त गरेकी हुन् । यस वर्णनमा कहिल्यै पानि मारेर मार्न नसकिने निर्धनता (गरिबी)ले गाउँलेलाई यति धेरै सताएको छ कि गाउँका केटाकेटीहरूका कपालमा जुम्रा परेर लिखा टल्केका छन् । नुहाउने, लुगा धुने साबुन पनि छैन, खान नपाएर मान्छेका आँखामा ओढार परिसकेको छ, छातीमा करड र शरीरमा हाडछाला मात्र छ। यहाँका मान्छेहरू पेटभरी खान नै पाउंदैन भने कसरी शिक्षा आर्जन गर्ने कर्ममा लाग्न सक्छन् ! भनिएको छ। त्यसकारण निर्धनताले गाँजेको यस्तो समाजमा खान त पाएको स्थिति छैन (भन्ने एउटा वर्णनबाट) भने शिक्षा आर्जन त के गरी गर्नु ! (भन्ने अर्को कुरा) असम्भव छ भन्ने स्वतः सिद्ध भएको हुँदा अर्थापत्ति अलड्कार छ।

\section{विषम}

लक्षण : विषमं यद्यनौचित्यादनेकान्वयकल्पनम् ॥६०॥ (जयदेव : १६४॥

अर्थात् अनुचित सम्बन्धवाला दुई विरोधीहरूलाई एकैसाथ वर्णन गरिएमा विषम अलड़कार हुन्छ। न्यायान्याय रहेन यो मुलुकमा गई्छन् कुनै पातक निर्धो नै ठहरिन्छ, आखिर गई अन्यायमा घातक। 
टोकी उफ्रन सक्छ। फुत्त उपियाँ जुम्रो पय्यो घानमा

सुन्दैनन् पनि सत्य हो जुन कुरो ठेडी हुने कानमा ॥३०॥ (द्वि.स., पृ. द२६)

यहाँ धनी त धनी छँदैछन्। गरीब चाहिँ धनी हुनुपर्ने भन्ने अभीष्टता हो तर यहाँ निर्धनका निम्ति न्याय गर्नु पर्नेले त्यसो नगरी पातक गर्दछन्। सत्य सुन्तु पर्ने अधिकारीहरूका कानमा ठेडी खाँदिएकाले सत्य कुरा सुन्दैनन् अनि निर्धो मानिस नै भन अन्यायका घानमा पर्दछ भनी कार्य कारणगत विषम स्थितिको वर्णन गरिएको हुँदा विषम अलड्कार छ। यस कुरालाई टोक्ने उपियो टोकेर उफ्रेर अन्तै भागिसक्छ अनि के ले पो टोक्यो भनी हेर्दा त जुम्रो भेटेर त्यसैलाई घानमा परेको जस्तो विषम स्थिति दर्शाउने लोकोक्ति मार्फत् पनि स्पष्ट पारिएको छ।

\section{लोकोक्ति}

लक्षण : लोकप्रवादानुकृतिर्लोकोक्तिरिति भण्यते ॥१५ ज॥ (कुवलयानन्द)

अप्पय दिक्षीतका मतमा वर्णनीय विषयलाई लोकव्यवहारमा फैलिएका उखानटुक्कादिको समेत अनुकरण गरी वर्णन गरेमा लोकोक्ति अलङ्कार हुन्छ (निरौला : २१६)।

त्यो नै ठीक थियो कि आज गरियो जे ठीक होला भनी,

भन्नै सक्छ र को किटेर पछि के कस्तो हुने हो अनि ।

काम्ला माथि मुछेर सातु घिनले छोड़दा हुने मूर्खता,

जे जे पर्दछ खप्तु पई जनले होल त जस्तो उता ॥२२॥ (द्वि.स., पृ.द२६)

यहाँ, वैरागिएर हिँडेका काव्यनायकलाई गाउँले बन्धुले घर फर्काएर ल्याई विवाह गराए पछि, उनी पहिले वैरागिएर हिंडेकै ठीक थियो कि, अहिले पुन: गृहस्थीमा प्रवेश गरेको कुन चाहिँ ठीक हो त ? भन्ने दोधार छ। भविष्यमा गृहस्थी जीवनमा केही अनर्थ भएर पछुताउने स्थिति पो आइपर्ने हो कि भन्ने शड्का पनि छ। आप्नो यस्तो अस्थिर मनस्थितिलाई चित्त बुकाउनका लागि उनले “काम्लामा (पाखीमा) सातु नमुछुनु, मुछेपछि घिनले नछोड्नु" भन्ने उखान सम्भेर गृहस्थी जीवनलाई स्वीकारेको सन्दर्भलाई व्यक्त गर्नका लागि प्रयोग गरिएको यस उखानले उक्तिचमत्कार उत्पन्न गरेको हुँदा लोकोक्ति अलङ्कार छ।

\section{स्वभावोक्ति}

लक्षण : स्वभावोक्ति: स्वभावस्य जात्यादिषु च वर्णनम् ॥२१११२॥ (जयदेव : २०१)

अर्थात् जहाँ कुनै कार्य, वस्तु, स्थिति, व्यक्ति आदिको स्वाभाविक वर्णन हुन्छ त्यहाँ स्वभावोक्ति अलड्कार हुन्छ।

गर्दा खोज तलास योग्य कुलकी कन्या मिलिन् सुन्दरी,

हेरी लग्न गरेर शान्ति विधिले देवादि पूजा गरी।

गाई मंगल वेदका नियमले होमाग्निको पूजन,

पूरा कर्म गरी लिई वर गए बाजा बजाई जन ॥१२॥ (द्वि.स., पृ.द२२)

यहाँ विवाह कर्मका निमित्त गर्नु पर्ने अड़भूत पूर्वकार्यहरू (जो बेहुलाका तर्फ सम्पन्न हुन्छन्)को वर्णन छ। जसमा कुल खान्दानकी योगय सुन्दरी कन्या हेर्ने, कुरो छिन्ने, विवाहका निम्ति लगन ठहर गर्ने वैदिक विधि विधान अनुसार नान्यमुखी, ग्रहपूजन, हवनादि र मंगलगान गर्दे कसार बटार्ने जस्ता कर्म पूरा गरी कन्यादन लिनका लागि बाजागाजा बजाउँदै जन्ती लिएर बेहुलो बेहुलीका घरमा गइने सनातन परम्पराको चमत्कारयुक्त स्वाभाविक वर्णन गरिएकाले स्वभावोक्ति अलङ्कार छ। 


\section{निष्कर्ष}

धनकुटाको फलाँटेमा जन्मस्थल भई सुनसरी, भापा, मोरझ़, पोखरा, देवघाट हुँदै अन्त्यमा पुन: धनकुटालाई नै कर्मभूमि बनाएर पू६। ४७ वर्षसम्म अध्यापन कार्यमा सक्रिय रहेका कृष्णप्रसाद वस्तीको कविता यात्राको प्रारम्भ २०१४ सालतिरबाट शुरू भएको मान्न सकिन्छ । उनले पद्यमा घरयासी चिठी लेखेर यसको प्रारम्भ गरेको देखिन्छ। पछि, उनको लेखन फुटकर कविता, समीक्षात्मक लेखन, निबन्धादि हुँदै खण्डकाव्य, स्मृतिकाव्य, शोककाव्य लेखनसम्म फैलिएको देखिन्छ। यसै ऋममा सेवानिवृत्त भएपछि, देवघाटमा अध्यापन गर्दाका बखतम (२०६५ साल)मा उनले यो 'दलबहादुर' खण्डकाव्य लेखेका हुन्। यो सामाजिक विषयवस्तुमा आधारित नायक प्रधान काव्य हो। यसमा कविले आफ्नै जन्मस्थान फलाँटेकै एक क्षेत्रीय वंशका सामान्य व्यक्तिलाई नायक बनाई उसकै जीवन चरित्रलाई ३ सर्गभित्र (शार्दूल विक्रीडित, शिखरिणी, मन्दाक्रान्ता र अनुष्टुप छन्दका) जम्मा २६० श्लोकमा अभिव्यक्त गरेका छन्। काव्यको अन्त्यमा नश्वर शरीरको अन्त्यलाई सास्वत रूपमा स्वीकार गर्दे दिवंगत आत्माको मुक्तिदायक तत्त्वका रूपमा श्रीमद्भागवत महापुराणको महिमा समेत प्रस्तुत गरिएको छ। पूर्वीय काव्यशास्त्रीय मान्यताको सीमाभित्र नै आबद्ध भई रचना गरिएको यो काव्यमा आलड्कारिक कविहरूले अलड्कारको प्रस्तुतिका लागि नै काव्य सिर्जना गरे जस्तो नभए पनि भावाभिव्यक्तिलाई सौन्दर्यमय ढड्ले प्रस्तुत गर्ने ऋममा स्वतः पर्न गएका छेकानु, वृत्यानु, श्रुत्यानु, अन्त्यानुप्रास जस्ता शब्दालड्कार तथा उपमा, रूपक, उत्प्रेक्षा, काव्यलिझ्ञ, दृष्टान्त, समुच्चय, विशेषोक्ति, अतिशयोक्ति, अर्थान्तरन्यास, अर्थापत्ति, उदात्त, स्मरण, विषम, लोकोक्ति, स्वभावोक्ति जस्ता अर्थाअलड्कारको विधान गरिएको छ। कविको सड़क्षिप्त जीवनी, कृतिको विवरण, 'दलबहादुर' खण्डकाव्यको कथावस्तु, विशेषता र अलड्कारको परिचय सहित यस काव्यमा विधान गरिएका $9 ९$ ओटा अलड़कारको सलक्षण वर्णनात्मक, विश्लेषणत्मक स्थितिलाई यस लेखमा अध्ययन गरिएको छ।

\section{सन्दर्भग्रन्थ सूची}

उप्रेती, गड्गाप्रसाद र अन्य (२०७५). (सम्पा.). नेपाली बृहत् शब्दकोश (द. सं.). काठमाडौं : नेपाल प्रज्ञा प्रतिष्ठान । जयदेव, (मि.न.). चन्द्रालोक पज्चमो मयुख. (व्या. श्रीकृष्णमणि त्रिपाठी). वाराणासी : चौखम्बा सुरभारती प्रकाशन । निरौला, लेखप्रसाद (२०७१). माधव घिमिरेका खण्डकाव्यमा अलड़ार. काठमाडौं : विद्यार्थी पुस्तक भण्डार । बराल, टीकादत्त (२०६६). (सम्पा.). तत्सम नेपाली व्युत्पत्ति कोश. काठमाडौँ : विद्यार्थी पुस्तक भण्डार । भट्टराई, गोन्दिराज (२०७३). पिताजी (वस्ती गुरु)का विभिध खण्डकाव्य. पण्डित कृष्णप्रसाद शर्मा वस्ती स्मृतिग्रन्थ. (सम्पा. ). गोविन्दराज भट्टराई र अन्य. धनकुटा : विश्रान्ति मन्दिर ।

मम्मट, (२००९ ई.). काव्यप्रकाश. (पु. मु.). (व्या.आचार्य विश्वेश्वर). वाराणासी : ज्ञानमण्डल लिमिटेड । रुद्रट, (१९६६ ई.). काव्यालड्कार. (व्या. रामेश्वर शुक्ल). वाराणासी : चौखम्बा विद्याभवन । वस्ती, कृष्णप्रसाद (२०७३). दलबहादुर. (सम्पा.). गोविन्दराज भट्टराई र अन्य. पण्डित कृष्णप्रसाद शर्मा वस्ती स्मृतिग्रन्थ. धनकुटा : विश्रान्ति मन्दिर ।

(२०७३). हाम्रा बाको गृहस्थाश्रममा प्रवेश. (सम्पा.). गोविन्दराज भट्टराई र अन्य. पण्डित कृष्णप्रसाद शर्मा वस्ती स्मृतिग्रन्थ. धनकुटा : विश्रान्ति मन्दिर ।

विश्वनाथ, (१९६४ ई.). साहित्यदर्पण. (व्या.कृष्णमोहन शास्त्री). वाराणासी : चौखम्बा संस्कृत संस्थान । श्रेष्ठ, ईश्वरकुमार (२०४४). पूर्वीय एवम् पाशचात्य साहित्य समालोचना : प्रमुख मान्यता, वाद र प्रणाली (द्वि. सं.). काठमाडौं : साभा प्रकाशन । 